\title{
«SIN TINO Y SIN PRETENSIONES». LA HIJA DEL MAR E O LABORATORIO GÓTICO
}

\section{César Domínguez}

Universidade de Santiago de Compostela

doi:10.17075/rcsxxi.2014.027

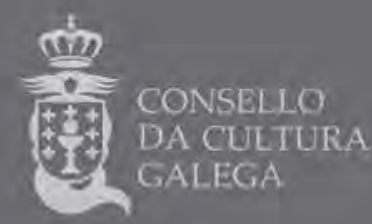



Álvarez, R. / A. Angueira / M. C. Rábade / D. Vilavedra (coords.) (2014): Rosalía de Castro no século XXI. Unha nova ollada, Santiago de Compostela, Consello da Cultura Galega. doi:10.17075/rcsxxi.2014. pp. 503-522

Lémbrense as palabras coas que o editor da Librería C. Bailly e Baillière de Madrid, responsábel da publicación en 1859 de La hija del mar a través da imprenta de Juan Compañel en Vigo, publicitou a novela de Rosalía de Castro:

La que presento al público [...] tiene sin disputa todas las cualidades y circunstancias que la caracterizan por una de las mejores en su clase. [...] Todas las perfecciones que se ven en esta obra deben aumentar la fama inmortal que la Escritora se ha adquirido ya por otras producciones literarias; $y$ es preciso confesar, al ver el plan tan bien trazado, y sus pasajes tan naturales, que tiene una imaginación y un caudal inagotable de imágenes, descripciones e ideas. [...] Dejo al lector por Juez de si son exageradas las perfecciones que ensalzo en la obra, que por consecuencia debe ser más imparcial que yo en su justicia. (cit. en López Santos 2010: 152).

Con seguridade, o lector decatouse do meu engano xa que non é posíbel que esta pasaxe teña algo que ver con La hija del mar, aínda que só sexa porque á altura da súa publicación non era factíbel «aumentar la fama inmortal que la Escritora se ha adquirido ya por otras producciones literarias». La hija del mar constitúe o «debut literario» de Rosalía de Castro (farase explícito máis adiante en que sentido técnico se emprega aquí o concepto de debut literario) precedido en 1857 pola publicación, na imprenta madrileña de M. González, do poemario La flor. Achámonos, xa que logo, ante o inicio da traxectoria artística da escritora, e non hai aínda pois «fama inmortal» que aumentar.

A pasaxe citada pertence ao prólogo de Carlos José Melcior á súa tradución ao castelán en 1818 de The Children of the Abbey, un best-seller gótico da inglesa Regina Maria Roche que rivalizou en popularidade con The Mysteries of Udolpho, de Ann Radcliffe. Poñer en relación este prólogo en xeral e a pasaxe citada en particular con La hija del mar non é, con todo, por completo gratuíto, aínda que as semellanzas con Óscar e Amanda, ou Los descendientes de la Abadía, título escolleito por Melcior, deban limitarse a sublin̄ar as «pasajes tan naturales», a «imaginación» e o «caudal inagotable de imágenes, descripciones e ideas». Máis 
aló, todo é aparentemente diferenzas. En contraste co "plan tan bien trazado» que Melcior destaca na novela de Roche, a novela de Castro foi caracterizada de «inmadura» (Carballo Calero 1979), «ingenua, irreal» (Costa Clavell 1985) e "folletinesca» (Mayoral 1986). E en contraste coa "clase», isto é, o xénero cuxos códigos se empregan na novela, tan obvio para o público español á altura de 1818, que Melcior non considera necesario especificalo con respecto á obra de Roche, a novela de Castro permaneceu até datas moi recentes nun limbo xenolóxico que, no mellor dos casos, non adquire máis concreción que a do modo folletinesco. Engádase a iso a canonización de Castro como escritora lírica e a súa actividade diasistémica (en castelán e galego) e teremos factores suficientes que xustifiquen o papel menor atribuído a La hija del mar.

A propia Rosalía de Castro, no Prólogo a La hija del mar, cualifica o seu relato como «escrito al azar, sin tino y pretensiones de ninguna clase», polo que o lector debería botalo «lejos de sí» e esquecer, «entre otras cosas, que su autor es una mujer». É máis, cualifica a súa aparición como un acto de «vanidad», «forzosa», trala publicación dos seus «primeros versos» (Castro 2005: 79), isto é, o poemario La flor. A crítica chamou a atención sobre a obvia ironía nestas palabras da autora, e iso, con todo, non reduciu un ápice a baixa estima en que foi tida esta novela.

Non é obxectivo deste traballo simplemente reivindicar nin a calidade intrínseca de La hija del mar nin defender para ela un lugar máis relevante, sexa no marco dunha historia da literatura en Galiza ou no dunha historia da literatura en castelán. A este respecto, debo aclarar que a obra rosaliana non constitúe en absoluto o meu campo de especialización, como tampouco o é, en termos xerais, a literatura galega. $\mathrm{O}$ meu achegamento é o dun comparatista, que na división académica do coñecemento vale tanto como dicir un especialista en todo e en nada ao mesmo tempo, aínda que prefiro decantarme pola segunda das definicións que Claudio Guillén (2005: 43) propuxera para a Literatura comparada: «lo que infunde vida y carácter propios a la Literatura comparada es un conjunto de problemas — con los que solamente ella puede y quiere encararse». Guillén (2005: 43) exemplificaba a demarcación disciplinaria dun deses problemas nos seguintes termos: «Los temas propios de la Literatura comparada se distinguen fácilmente: la novela realista europea le corresponde, sin duda, mientras que la novela pastoril española es tarea para hispanistas». Substitúase «novela realista europea» por «novela gótica europea» e pregúntese verbo da existencia dunha 
«novela gótica española», e creo que teremos suscitado un problema comparatista cuxa relación dialéctica coa historiografía literaria de corte nacional pode ser produtiva en ambas as dúas direccións.

É ben sabido que La hija del mar foi lida, en reiteradas ocasións, en clave autobiográfica. A proposta que aquí se fai é distinta no sentido en que se propón unha clave «bioliteraria». De feito, a propia Rosalía de Castro solicitaba esta clave dende o seu Prólogo cando sinalaba como a publicación de La flor en 1857 conduciu á da súa primeira novela dous anos máis tarde no marco do «gran mar de las publicaciones actuales» (Castro 2005: 79). A miña lectura presenta a Castro como «filla do mar» literario, unha filla cuxos lazos familiares se problematizan en distintas direccións. Para desenvolver a miña proposta detereime, en primeiro lugar, nunha análise prosopográfica do debut literario da escritora para, en segundo lugar, interrogar o que considero produtiva marxinalidade de La hija del mar en termos de xénero literario. Finalmente, intentarei reler as principais conclusións das seccións primeira e segunda á luz do que Sigmund Freud chamou Familienroman (novela da familia).

\section{ROSALÍA DE CASTRO COMO MEMBRO DA COHORTE DE 1859}

Sintomaticamente, Rosalía de Castro é unha autora que non pode ser integrada nunha «familia literaria», é dicir, unha xeración literaria, excepto intentos moi puntuais, como o da súa inclusión na chamada "xeración becqueriana», xunto con Eusebio Blasco, Narciso Campillo, Augusto Ferrán, Luís García Lúa, Florencio Moreno Godino, Julio Nombela, Manuel del Palacio, Ramón Rodríguez Correa e Eulogio Florentino Sanz. En todo caso, as limitacións do método xeracional son ben coñecidas. En termos xerais, a exposición que sobre elas realiza Hans Jaeger, en especial a referida ás aplicacións historiográficas, segue sendo de utilidade. Aínda que puidesen ser rectificadas, en calquera caso, a xeración preséntasenos como unha agrupación de escritores que, a posteriori, recoñecen certa comunidade de intereses na súa obra, reflectida no que pode denominarse xenericamente «norma literaria». Esta norma explica a súa obra e, a un mesmo tempo, a súa diferenza con respecto á norma doutros escritores, que non son acolleitos 
entre as súas filas. En ocasións, a loita acaba por ser máis un medio para lograr o recońecemento social que para formar unha auténtica escola.

Fronte ao método xeracional, decanteime nesta ocasión polo que denomino un «método pre-xeracional», para o que a prosopografía pode proporcionarnos unha ferramenta de utilidade. Donald Broady (2002: 381-382) define a prosopografía como «a kind of collective biography [...] based on a comprehensive collection of data» cuxo obxectivo «is not the individuals per se but rather the history and structure of the field». Mediante a proposta de Rolf Lundén, Bo G. Ekelund e Mattias Bolkéus Blom, trátase de establecer unha cohorte a partir da entrada do escritor no campo literario, entrada que se define polo ano de publicación dunha obra extensa de ficción. No caso de Castro, o ano do seu debut é 1859, coa publicación de La hija del mar. Para a recolección de datos co fin de establecer a cohorte de debutantes literarios en 1859, baséome fundamentalmente no volume oitavo da Historia de la lengua y literatura castellana de Julio de Cejador y Frauca, pois organízase, rechamantemente, por anos de debut, con Rosalía de Castro incluída en 1857 (entrada núm. 69). Limítome a rexistrar os autores que debutan en España, aínda que Cejador y Frauca tamén informa de todos os autores castelanfalantes que fan a súa entrada no ano en cuestión.

Obviamente, existe unha discrepancia entre o ano escolleito por Cejador y Frauca, 1857, cando se publicou La flor, fronte a 1859, polo que eu me decanto a raíz de La hija del mar. A xustificación da miña elección reside nos procedementos do método prosopográfico, para o que se considera como ano de debut para a análise das cohortes aquel que cumpre cun criterio de extensión. A “"prosefiction debut" is understood here», afirman Lundén, Ekelund e Bolkéus Blom, "as a book-length publication, that is, a short story collection or a novel, written for adults and included as such in one of the various publishing records» (2002: 303). La flor é unha colección de sete poemas que ocupa ao redor de trinta páxinas. Certamente, poderase obxectar que a concentración na produción en prosa resulta dificilmente aceptábel no caso dunha escritora como Rosalía de Castro. É máis, trataríase dun exercicio que non fai máis que trocar o criterio de canonización da escritora, que pasou por eloxiar a súa produción poética en detrimento da prosística. Estou totalmente de acordo e recoñezo que o método prosopográfico presenta serias dificultades para analizar escritores que practicaron diversos xéneros literarios. É máis, o método tampouco contempla como afrontar o estudo 
de escritores que empregan máis dunha lingua literaria, como sucede con Castro. Sendo plenamente consciente destes problemas e interrogantes, o recurso á prosopografía pola miña banda ten un carácter experimental que persegue (re)ler unha obra extensa en prosa: La hija del mar. Non se esqueza, neste sentido, que a propia autora no Prólogo sublińou a relación causal entre o poemario e a novela, ambos escritos en castelán: «Publicados mis primeros versos la aparición de este libro era forzosa casi» (Castro 2005: 79). Cal poida ser a natureza desa causalidade "forzosa» é materia de conxectura, pero é innegábel que Castro percibiu un nexo importante para a súa nacente traxectoria literaria. E, en termos «familiares» —os da familia íntima, pero tamén os da familia literaria-, non pode pasarse por alto a encomiástica recensión que do poemario publicou Manuel Murguía o 12 de maio de 1857 no diario madrileńo La Iberia. Nela xa fan a súa aparición os primeiros síntomas de mitificación e, en palabras de Alejandro Alonso Nogueira (1999: 43), de "traxectoria imaxinada», posto que Murguía afirma non coñecer a escritora cando, en realidade, o seu encontro xa se produciu cara a 1854. Para esa traxectoria, Murguía (1857) albisca un destino glorioso: «trabajad y ocuparéis un lugar honroso en nuestra literatura patria». Celebradas as súas nupcias en outubro de 1858, a Dedicatoria da escritora ao marido incluída en La hija del mar contradí seriamente a opinión que sobre a súa novela inclúe a continuación no Prólogo: «creo que es la mejor ofrenda que puede presentarte tu esposa» (Castro 2005: 76).

Estes datos de ningún xeito poden ser considerados definitivos xa que esixen unha investigación documental moito máis profunda, que deberá ser abordada no futuro. Malia a súa provisionalidade, é innegábel que, dos seus sete compañeiros de cohorte, e aínda que a súa traxectoria editorial é a terceira máis breve (27 anos), o que debe poñerse en relación co feito de que a súa vida foi a segunda máis curta tras Bernardo López García, só Rosalía de Castro permanece hoxe día na memoria do gran público e a súa obra segue sendo lida. Até para a historia da literatura en castelán, a maioría destes autores desapareceron, excepto para unha historia da produción literaria, como a practicada por Cejador y Frauca. Talvez só resistan unha mínima comparación as traxectorias editoriais de Gaspar Núñez de Arce (27 anos) e Faustina Sáez de Melgar (31 anos). 
Cohorte de escritores españois de ficción que debutaron en 1859

\begin{tabular}{|c|c|c|c|c|c|}
\hline Escritor & $\begin{array}{l}\text { Nacemento } \\
\text { - } \\
\text { Defunción }\end{array}$ & $\begin{array}{l}\text { Obra } \\
\text { (primeira e derradeira) }\end{array}$ & $\begin{array}{l}\text { Ano de } \\
\text { publicación }\end{array}$ & Xénero & Profesión \\
\hline $\begin{array}{l}\text { Rafael del } \\
\text { Castillo }\end{array}$ & $?-?$ & $\begin{array}{l}\text { El honor de España } \\
\text { Maldita sea la guerra }\end{array}$ & $\begin{array}{l}1859 \\
1874 \\
\end{array}$ & $?$ & $\begin{array}{l}\text { Novelista } \\
\text { Xornalista } \\
\end{array}$ \\
\hline $\begin{array}{l}\text { Rosalia de } \\
\text { Castro } \\
\end{array}$ & $1837-1885$ & $\begin{array}{l}\text { La hija del mar } \\
\text { En las orillas del Sar }\end{array}$ & $\begin{array}{l}1859 \\
1884 \\
\end{array}$ & $\begin{array}{l}\text { Novela } \\
\text { Poesía } \\
\end{array}$ & Escritora \\
\hline $\begin{array}{l}\text { Amós de } \\
\text { Escalante y } \\
\text { Prieto }\end{array}$ & 1831-1902 & $\begin{array}{l}\text { Traducción de poemas de } \\
\text { Victor Hugo } \\
\text { Diamante del corazón }\end{array}$ & $\begin{array}{l}1859 \\
1910\end{array}$ & $\begin{array}{l}\text { Poesía } \\
?\end{array}$ & Xornalista \\
\hline $\begin{array}{l}\text { José } \\
\text { González } \\
\text { de Tejada }\end{array}$ & $1833-1894$ & $\begin{array}{l}\text { Camino del matrimonio } \\
\text { Cuentos caseros }\end{array}$ & $\begin{array}{l}1859 \\
1872 \\
\end{array}$ & $\begin{array}{l}\text { Comedia } \\
\text { Relatos }\end{array}$ & Maxistrado \\
\hline $\begin{array}{l}\text { Bernardo } \\
\text { López } \\
\text { García }\end{array}$ & $1838-1870$ & $\begin{array}{l}\text { Al Asia } \\
?\end{array}$ & $\begin{array}{l}1859 \\
?\end{array}$ & $\begin{array}{l}\text { Poesía } \\
\text { ? }\end{array}$ & $\begin{array}{l}\text { Político } \\
\text { Poeta }\end{array}$ \\
\hline $\begin{array}{l}\text { Gaspar } \\
\text { Núñez de } \\
\text { Arce }\end{array}$ & $1832-1903$ & $\begin{array}{l}\text { La cuenta del zapatero } \\
\text { Maruja }\end{array}$ & $\begin{array}{l}1859 \\
1886\end{array}$ & $\begin{array}{l}\text { Comedia } \\
\text { Poesía } \\
\text { narrativa }\end{array}$ & $\begin{array}{l}\text { Xornalista } \\
\text { Político }\end{array}$ \\
\hline $\begin{array}{l}\text { Juan Palou } \\
\text { y Coll }\end{array}$ & $?$ & $\begin{array}{l}\text { La campana de la } \\
\text { Almudaina } \\
\text { Don Pedro Puñalet }\end{array}$ & $\begin{array}{l}1859 \\
1900\end{array}$ & $\begin{array}{l}\text { Cuadro } \\
\text { histórico } \\
\text { Drama } \\
\end{array}$ & $?$ \\
\hline $\begin{array}{l}\text { Faustina } \\
\text { Sáez de } \\
\text { Melgar }\end{array}$ & $1834-1895$ & $\begin{array}{l}\text { La lira del Tajo } \\
\text { El hogar sin fuego y la } \\
\text { bendición paterna }\end{array}$ & $\begin{array}{l}1859 \\
1890\end{array}$ & $\begin{array}{l}\text { Poesía } \\
\text { Novela }\end{array}$ & $\begin{array}{l}\text { Escritora } \\
\text { Xornalista }\end{array}$ \\
\hline
\end{tabular}

Pero a comparación das traxectorias de Rosalía de Castro, Gaspar Núñez de Arce e Faustina Sáez de Melgar non só resulta de interese pola súa duración aproximada e por conseguir, estes dous últimos, sobreviviren ao esquecemento académico, que non ao esquecemento do público xeral, senón moi fundamentalmente polas singularidades das devanditas traxectorias. Núñez de Arce construíu a súa carreira literaria fundamentalmente mediante unha poesía narrativa sentimental, cunha linguaxe non afectada e de raizame anglosaxoa, que vińa a opoñerse, en palabras de Jorge Urrutia (1983: 500), non á poesía de Bécquer, senón á poesía becqueriana. Sáez de Melgar, pola súa banda, achou, nunha novela sentimental, a razón de practicamente unha anual durante vinte anos, que exaltaba os valores do conservadorismo social, a clave do seu éxito. Máis aló do seu coñecemento 
da literatura europea, que traduciu activamente, dos seus escritos a favor dos dereitos das mulleres e das consecuencias que para a súa carreira literaria supuxo o seu traslado a Madrid en 1855, as carreiras literarias de Núñez de Arce e Castro parecen asentarse en opcións de xénero contrapostas para realizar a súa entrada no campo literario.

Mentres as novelas sentimentais de Núñez de Arce como, por exemplo, La pastora de Guadiela, celebran a figura do "anxo do fogar», a tenrura da muller delicada que como esposa e nai mantén a harmonía do espazo doméstico dunha clase social economicamente dominante (García Jáñez 2005), Castro preséntanos, en La hija del mar, unha situación completamente oposta: a destrución do núcleo familiar baixo a ameaza masculina entre as clases menos privilexiadas. $\mathrm{Cal}$ é o xénero prototípico que na época, e máis tarde, permite a exploración desta temática está ben claro a nivel europeo, pero non tanto no caso espańol e menos aínda parece ser, a teor das valoracións da crítica, no caso de Rosalía de Castro. E, con todo, en data tan temperá como 1972, a escritora e tradutora Ma Teresa Barro xa adiantara as respostas xeral e particular. Polo que á resposta xeral se refire, está contida na súa propia pregunta: «Atrevereime a dicir que as novelas de Rosalía son as únicas novelas europeas que se escribiron na Península?». Con respecto á resposta particular, a súa afirmación é suficientemente explícita: « $\mathrm{La}$ hija del mar de Rosalía de Castro é irmá de Jane Eyre e de Cumbres borrascosas» (Barro 1972: 328).

\section{ROSALÍA DE CASTRO EN HAWORTH - AS BRONTË EN MUXÍA}

Unha vez máis, achámonos ante a imaxe da familia, neste caso, ante uns lazos de consanguinidade que fan de Rosalía de Castro a "cuarta» das irmás Brontë e de La hija del mar unha novela gótica (feminina). No monográfico máis recente sobre o gótico en Espańa, Miriam López Santos persegue «recuperar una producción novelística olvidada y mal comprendida, y vincularla al fenómeno universal de la ficción gótica, con sus deudas y con sus elementos diferenciadores y propios, aportándole, en definitiva, la razón de su existencia» (2010: 13).

Esa recuperación non alcanza, con todo, a La hija del mar, pois López Santos circunscribe o seu estudo ao período 1788-1833, que vén determinado por «el 
mantenimiento del régimen absolutista durante los reinados de Carlos IV y Fernando VII» (2010: 13). Postula, pois, a autora unha relación directa entre absolutismo e cultivo do xénero gótico en España, un cultivo que, segundo afirma, transcende "la vigencia del género en los restantes países europeos (1764-1820)» (López Santos 2010: 13). Implicitamente, en consecuencia, tamén se postula un décalage do gótico en España con respecto ao resto de Europa, pois o seu inicio en 1788 viría marcado pola tradución por Fernando Gilman de Les Veillés du châteaux, ou cours morale à l'usage des enfants, de Caroline-Stéphanie-Felicité du Crest, e clausúraa en 1833-1834 pola publicación de El hombre invisible, o Las ruinas de Munsterhall e La urna sangrienta, o El panteón de Scianella, ambas as dúas do valenciano Pascual Pérez Rodríguez.

Con independencia do ano específico de arranque do gótico europeo, moito máis problemática resulta a súa clausura en 1820, que leva a López Santos a afirmar que «la segunda fecha [1833] trasciende [...] con mucho (unos trece años), la vigencia del género gótico en el resto de los países del entorno» (2010: 17-18). Obviamente, un enfoque dirixido cara á supervivencia literaria e intermedialidade do gótico podería levarnos até datas moi recentes, como 1992, co Bram Stoker's Dracula, de Francis Ford Coppola, 2000, con Magic Terror: Seven Tales, de Peter Straub, ou 2001, con Los otros, de Alejandro Amenábar. Pero é que, até dende perspectivas literarias máis conservadoras, a cronoloxía do gótico supera con moito o límite de 1820 que López Santos dá por aceptado. Alison Milbank, por exemplo, explora o gótico victoriano entre 1830 e 1880; Eric Savoy, o gótico estadounidense entre 1798 e 1898 (ano de publicación de The Turn of the Screw); e Kelly Hurley, o gótico británico entre 1885 e 1930.

Resulta difícil comprender por que o período 1788-1833 debería permitir acabar coa «cerrazón de los críticos», en palabras de López Santos, a cal «les ha llevado a defender la tesis de la inexistencia de una verdadera novela gótica en nuestra literatura» (2010: 18) cando, en realidade, implica un desfase cronolóxico do gótico en España, deixa fóra novelas de innegábel factura gótica (como é o caso de La hija del mar) e a cronoloxía europea proposta (1764-1820) resulta ser moi restritiva con respecto á proposta por outros investigadores do gótico. A este respecto, talvez deba concluírse unha excesiva dependencia das formulacións de Maurice Lévy con respecto ao gótico inglés, quen en 1968 fixou o seu cultivo entre 1764 e 1824. En definitiva, López Santos propón como cronoloxía xeral 
do gótico aquilo que na actualidade tan só se considera a súa «primeira onda» (Norton 2000).

Sexa como for, é innegábel a relevancia da achega de López Santos ao incorporar no seu estudo a análise das traducións ao castelán de novelas góticas inglesas, francesas e alemás, xa se trate de traducións no sentido máis ou menos contemporáneo do termo ou en canto «traducións adaptadas». Como afirma a autora:

Aunque faltaron algunos nombres y novelas claves del género y la vertiente racional predominó, en detrimento de la irracionalista, se conoció un elenco bastante importante de autores, mayores y menores, ingleses y de otras literaturas, y muchos de ellos en sucesivas reediciones, que permitieron que penetrara el gusto por la oscuridad y que los lectores lo demandaran. Ninguna corriente importada fue en materia de traducción especialmente prolífera en aquel período tan complicado para nuestras letras, pero, en medio de la oscuridad, la novela gótica no desfalleció en la tarea de abrirse paso y dejó destellos que prepararían el camino al Romanticismo, que ya llamaba con insistencia a nuestras puertas. (2010: 51).

O exercicio de close reading (lectura próxima) que realiza sobre as traducións ao castelán presenta datos adicionais que xustifican as conclusións ás que chegara en 1997 Franco Moretti mediante o método de distant reading (lectura distante). No Atlante do romanzo europeo, 1800-1900, Moretti cartografa o xénero gótico inglés dende o punto de vista non da difusión na produción do xénero, senón dende o da súa ambientación. Rechamantemente, é un dos escasos mapas literarios de Moretti que carece de lenda, de tal forma que descońecemos con exactitude tanto cales son as novelas e relatos que lle proporcionan os datos de ambientación como a cronoloxía destas obras. O corpus da súa cartografía está constituído por uns sesenta textos, con respecto aos cales chama a atención sobre a falsa sensación de sincronía que se deriva do seu propio mapa: «el gótico está ambientado inicialmente en Italia (y Francia); después se desplaza hacia el norte, en Alemania, alrededor de 1800; y luego aún más al norte, a Escocia, alrededor de 1820» (2001: 16).

Aínda que non podo afirmalo con total seguridade, intúo que a fonte sobre a que Moretti aplica a súa distant reading é o xa citado clásico estudo de Maurice Lévy, pois a el se remite nos seus gráficos sobre as formas hexemónicas británicas 
entre 1760 e 1850 no seu libro posterior Graphs, Maps, Trees (Moretti 2005: 15). Como sinalei antes, non é un mapa de difusión xenolóxica, senón un mapa de ambientación. Iso non significa, no entanto, que non existan concomitancias relevantes. O propio Moretti sinala que «la máxima concentración de cuentos góticos está situada en el triángulo comprendido entre el Rin, la Selva Negra y el Harz (la región del pacto con el diablo): distribución geográfica en la que probablemente influye el enorme número de textos góticos escritos en alemán (y hoy olvidados)»(2001: 16). Neste mesmo sentido, quizais poida considerarse que o limitado uso de España como espazo de ambientación do gótico por parte dos escritores ingleses se debe ao papel menor no cultivo do gótico polos escritores españois dentro do panorama europeo, que é facilmente mensurábel en función dos fluxos de tradución, cunha balanza totalmente desequilibrada cara á importación de textos ingleses e franceses, cun papel mediador reservado en exclusiva a Francia e cun interese dominante polo «gótico feminino» (Establier Pérez 2010).

Apreciouse que a localización dun ambiente gótico en España por parte dos relatos ingleses se limita ao terzo meridional. Tanto a dependencia de Lévy por parte de Moretti e, en consecuencia, a súa limitación ao período 1764-1824, así como a súa restrición a obras inglesas, introducen dúbidas verbo de que esta sexa realmente a cartografía literaria do xénero. Nestes momentos, David Taboada e eu mesmo estamos a traballar na cartografía do gótico producido en España, incluídas as "traducións adaptadas». De confirmarse a localización detectada por Moretti, habería que concluír que a localización de La hija del mar na Costa da Morte, en xeral, e en Muxía, en particular, constitúe unha excepción baixo a óptica nacional. Agora ben, contemplada esa localización comparativamente, a súa excepcionalidade queda seriamente cuestionada. Tómese en consideración a este respecto que o mapa do gótico debido a Moretti dialoga directamente con outro dos seus mapas, o da novelística de Jane Austen, até o extremo de que ambos os dous responden a unha mesma matriz xeográfica que a propia Austen revela na súa novela póstuma e pseudogótica, The Northanger Abbey.

Charming as were all Mrs. Radcliffe's Works, and charming even as were the works of all her imitators, it was not in them perhaps that human nature, at least in the Midland counties of England, was to be looked for. Of the Alps and Pyrenees, with their pine forests and their vices, they might give a faithful delineation; and Italy, Switzerland, 
and the South of France, might be as fruitful in horrors as they were then represented. Catherine dared not doubt beyond her own country, and even of that, if hard pressed, would have yielded the northern and western extremities. But in the central part of England there was surely some security for the existence of a wife not beloved, in the laws of the land, and the manners of the age. Murder was not tolerated, servants were not slaves, and neither poison nor sleeping potions to be procured. (Austen 2008: 147; lib. II, cap. 10).

Mrs. Radcliffe é obviamente Ann Radcliffe, a famosa novelista cuxos relatos góticos engaiolaran a un público maioritariamente feminino que, na súa parodia de The Mysteries of Udolpho, Jane Austen singulariza na protagonista de Northanger Abbey, Catherine Morland. A xeografía do gótico que Austen propón para o continente coincide punto por punto co mapa de Moretti. No caso das illas británicas, o gótico nelas queda relegado ao oeste e ao norte (Cornualles, Gales, Irlanda e Escocia), é dicir, a periferia céltica que o mercado colonizou cara a 1820, mentres que o sur de Inglaterra é o territorio que dá sentido á novelística de Austen e que a novelística de Austen constrúe como o espazo imaxinado das propiedades territoriais da alta burguesía e da aristocracia, nas que as raparigas están destinadas a converterse en «anxos do fogar»e, no peor dos casos, de fracasar o seu matrimonio, en mulleres protexidas pola lei e a moral.

Creo chegado o momento de afirmar que a matriz xeográfica que dá sentido á novelística de Austen e ao xénero gótico ten a súa correspondencia en España, respectivamente, coa novelística, por unha banda, das chamadas «escritoras isabelinas», entre as que se contan a xa mencionada Faustina Sáez de Melgar ou Pilar Sinués de Marco, quen o mesmo ano de La hija del mar publicou El ángel del hogar, obra moral y recreativa dedicada a las mujeres, e, pola outra banda, Rosalía de Castro cunha novela gótica ambientada no «embravecido mar de Finisterre» (Castro 2005: 99), en «tristes paisajes» (Castro 2005: 100), nun «olvidado rincón de Europa» (Castro 2005: 102), que merecesen ser descritos por E. T. A. Hoffmann e Lord Byron:

Lugar este el más apartado y salvaje de aquella comarca, tiene cierta ruda belleza digna de ser descrita por Hoffmann, y que tal vez sólo puede ser grata a los caracteres tétricos o a las imaginaciones exaltadas. 
Si Byron, ese gran poeta, el primero sin duda alguna de este siglo, hubiese posado sobre el desnudo cabo de Finisterre su mirada penetrante y audaz, hubiéramos tenido hoy, tal vez, un cuadro más en su Manfredo (Castro 2005: 102)

\section{SOBRE AS MÚLTIPLES MARXINALIDADES DE LA HIJA DEL MAR}

La hija del mar non só está ambientada en «aquel desolado rincón del mundo» (Castro 2005: 83), senón que tamén é plenamente consciente da súa creación dende «aquel desolado rincón del mundo», un mundo literario a cuxas grandes figuras femininas Castro invoca dende o Prólogo, desde as máis próximas (Manon Philipon, Madame de Staël, George Sand) até as afastadas no tempo (Tareixa de Xesús, Safo, Catarina de Rusia, Xoana de Arco e María Tareixa de Austria). Engádase a iso a súa afirmación, antes citada, verbo do espazo galego como merecedor do gótico practicado por un Hoffmann ou un Byron. Pero a marxinalidade non só é a do capital cultural na xeografía literaria, senón tamén de xénero, pois, como afirma Castro ao pechar o seu Prólogo, «todavía no les es permitido a las mujeres escribir lo que sienten y lo que saben» (2005: 79).

Os referentes cos que a nova escritora se relaciona no seu debut literario aos vinte e dous anos, desde os incluídos no Prólogo até os que lle proporcionan os limiares que introducen cada capítulo, son impresionantes, até o punto de que, como resultado do descońecemento que temos sobre a biblioteca de Rosalía de Castro, moi recentemente Montserrat Ribao Pereira baseouse neles para reconstruíla e concluír que a «biblioteca rosaliana da súa mocidade, do tempo anterior a Murguía e Heine, a Cantares, Follas novas ou En las orillas do Sar, é a dunha escritora con firme vocación de selo, que rastrexa materiais para os seus textos, emprégaos significativamente e nolos mostra» (2012: 47).

Certamente, contribúen á creación dunha atmosfera gótica as citas procedentes do Manfred de Byron, do Werther de Goethe, do sublime no Ossian de James Macpherson ou das novelas históricas de Carl Franz van der Velde. Chamarei a atención aquí, con todo, sobre dúas escritoras, a novelista inglesa Charlotte Turner Smith e a novelista estadounidense Maria Susanna Cummins. Smith, a través da súa novela Emmeline, The Orphan of the Castle (1788), proporciónalle a Castro o limiar para o capítulo 12 (Lorenzo), que cita en castelán. Non achei documen- 
tación sobre unha posíbel tradución ao castelán; si foi traducida, en cambio, ao francés o mesmo ano da súa publicación en inglés. Trátase dunha novela fundacional da tradición gótica. Cummins, a través da súa novela The Lamplighter, de 1854, proporciónalle a Castro os limiares para os capítulos 9 (Tormentos) e 15 (La loca), que cita en francés. The Lamplighter, que combina o modo gótico na súa primeira parte co Bilgunsroman na segunda, cońeceu en 1855 dúas traducións ao francés a cargo de Émile da Bédollière e Frédéric-Germain de Lagny.

Estes dous datos son unha mostra significativa dese «mar literario» no que Rosalía de Castro se mergulla, alimentado como nunca antes por escritoras. Lémbrese a este respecto como Nathaniel Hawthorne lle escribe dende Liverpool, onde exercía como cónsul, ao seu editor William Ticknor en xaneiro de 1855 para facerlle saber as razóns polas que non recibiu un manuscrito seu en tanto tempo: "America is now wholly given over to a damned mob of scribbling women, and I should have no chance of success while the public taste is occupied with their trash—and should be ashamed of myself if I did succeed». E a continuación pregúntase: «What is the mystery of these innumerable editions of the Lamplighter, and other books neither better nor worse? - worse they could not be, and better they need not be, when they sell by the 100,000» (cit. en Baym 1999: 21). A cita é suficientemente elocuente verbo do desconcerto de Hawthorne ante un novo panorama literario, dominado por escritoras cuxas obras se converten de forma inmediata en best-sellers nun mercado internacional transatlántico. A primeira edición de Emmeline, duns mil cincocentos exemplares, esgotouse en poucas semanas, polo que foi necesario preparar rapidamente unha segunda edición. $\mathrm{O}$ impresor, Thomas Cadell, responsábel durante eses anos da edición de Decline and Fall of the Roman Empire, decidiu recompensar a Smith cuns honorarios moi superiores aos inicialmente prometidos. Engádase a iso a súa tradución ao francés o mesmo ano da súa publicación en inglés. The Lamplighter, a novela deostada por Hawthorne, vendeu 20000 exemplares en vinte días e 65000 ao cabo de cinco meses, o que a converteu no segundo best-seller tras Uncle Tom's Cabin, de Harriet Beecher Stowe. En Inglaterra vendéronse ao redor de 100000 exemplares e poucos meses logo da súa publicación foi traducida ao francés.

Rosalía de Castro, en consecuencia, era boa coñecedora da tradición gótica, dende unha obra fundacional como Emmeline, sobre a que descońecemos se tivo acceso a ela na tradución francesa ou a través de comentarios da prensa, até os 
éxitos máis recentes - The Lamplighter — que lera na versión francesa de 1855, catro anos antes de realizar a súa propia achega ao gótico internacional. E é neste momento cando adquire toda a súa relevancia volver á frase final do seu Prólogo a La hija del mar: «todavía no les es permitido a las mujeres escribir lo que sienten y lo que saben» (2005: 79).

Como mencionei ao principio, só en datas moi recentes a crítica se achegou a unha lectura de La hija del mar en clave gótica. En 2012, Leigh Mercer propuxo unha lectura comparativa entre esta novela e La sombra, de Benito Pérez Galdós, xa que, na súa opinión, ambas as dúas novelas «make use of the Gothic as a way to express concerns about gender and society in the Spanish nineteenth century» (2012: 34). No caso de Galdós, Mercer vincula La sombra ao gótico internacional a través de The Castle of Otranto, de Horace Walpole, mentres que para La hija del mar recorre a Jane Eyre e Wuthering Heights, ambas as dúas publicadas en 1847. A novela de Charlotte Brontë coñeceu unha tradución ao francés en 1855, mentres que a da súa irmá Emily non parece ter sido traducida até datas moi posteriores. Coa dúbida que poida suscitar o caso de Jane Eyre e o seu cońecemento por Castro, que chegou a forzarse, na miña opinión, a través da hipótese de que a autora puidese ter asistido á representación de Juana Eyre: drama en cuatro actos, aínda que o manuscrito de Francisco Morera e Valls data de 1859, o certo é que a súa mención pola crítica responde á súa moderna canonización, fronte á enorme cantidade de publicacións góticas que foron un éxito de vendas e coñeceron difusión internacional no seu momento, pero que foron relegadas ao esquecemento na actualidade, como sucede con Charlotte Turner Smith e Maria Susanna Cummins, que si foron coñecidas por Rosalía de Castro.

En calquera caso, da proposta de Mercer resúltame especialmente interesante a súa filiación Walpole-Galdós, por unha banda, e Brontë-Castro, pola outra, xa que incide nesa formulación que mencionei nun par de ocasións: a dun «gótico feminino». Fronte ao gótico masculino asentado na noción freudiana de conflito edípico en tanto que nos presenta "some "son" both wanting to kill and striving to be the "father" and thus feeling fearful and guilty about what he most desires» (Hogle 2004: 5), o gótico feminino presenta a muller como o Outro, un «object of exchange», «the merest tool of child-bearing between men» e constrúese sobre o motivo central do esquecemento: «a patriarcal lineage and house turns out to be 
explicitly dependent on and rooted in the unpredictable possibilities of a forgotten, but finally uncovered, womanhood» (Hogle 2004: 10).

Coa frase final do seu Prólogo, Rosalía de Castro alude explicitamente a un saber-Outro e a un sentir-Outro, que foron reprimidos polo patriarcado. A través do gótico, en La hija del mar Castro atopa un laboratorio en que non só ensaia o seu debut e ingreso no campo literario, senón tamén, e máis importante, explora a orfandade feminina e a posibilidade dunha lińaxe exclusivamente feminina, que se materializa no triángulo delimitado por Teresa (ela mesma expósita), Candora e Esperanza. Xa non estamos ante os delicados anxos do fogar das escritoras isabelinas, senón ante as «frescas y robustas hijas de aquellas montańas que comunican su salvaje belleza a sus moradores» (Castro 2005: 86), «vagamundas» (Castro 2005: 93) axexadas polo ameazante poder masculino que aquí encarna nada menos que o pirata escravista Alberto Ansot. Pero o gótico de La hija del mar foi tamén o laboratorio que lle permitiu experimentar coa posibilidade dunha escrita por parte dunha muller —orfa literaria que invoca unha pléiade de «nais adoptivas»— que o poder masculino só pode rexeitar como acto de vaidade, «ese pecado de la mujer», di Castro, «de que, ciertamente, no está muy exento el hombre» (2005: 79).

O debut gótico que supón La hija del mar, tal e como intentei presentalo aquí, quizais poida proporcionar novas claves para a traxectoria posterior de Rosalía de Castro, da que o gótico non está ausente, como demostrou, tamén en 2012, Isabel Clúa Ginés (2012) na súa lectura de El caballero de las botas azules. A lectura que aquí presento non esgota, dende logo, os experimentos que Rosalía de Castro practicara con La hija del mar. Se Galiza se nos presenta como un espazo de alteridade, do mesmo xeito que o era a periferia céltica para a novelística de Jane Austen, non se pode pasar por alto que esa alteridade se encarna nun modelo-Outro de familia. Margot Gayle Backus (1999) recorreu ao estudo da neurose tal e como fora presentado por Freud no modelo do Familienroman. Segundo Freud, a novela familiar é un sistema en que o neno se resitúa na sociedade mediante, por unha banda, fantasías sobre orfandade e adopción e, pola outra banda, mediante fantasías que implican infidelidades sexuais por parte da súa nai. Claramente, La hija del mar preséntanos outro sistema de Familienroman, no que o gótico lle permite cuestionar o modelo patriarcal de domesticidade, o modelo patriarcal de autoría literaria e o modelo nacional de territorialización. Pero son estas cuestións que exceden xa os límites do presente traballo e serán obxecto de estudo proximamente. 


\section{REFERENCIAS BIBLIOGRÁFICAS}

Alonso Nogueira, Alejandro (1999): «A invención do escritor nacional. Rosalía de Castro: a poeta e a súa patria», en Rosario Álvarez / Dolores Vilavedra (eds.), Cinguidos por unha arela común. Homenaxe ó profesor Xesús Alonso Montero, Santiago de Compostela, Universidade, 2, 41-64.

Austen, Jane (2008): Northanger Abbey, Lady Susan, The Watsons, Sanditon. [Eds. James Kinsley e John Davie]. Oxford, Oxford University Press.

Backus, Margot Bayle (1999): The Gothic Family Romance: Heterosexuality, Child Sacrifice and the Anglo-Irish Colonial Order, Durham, NC, Duke University Press.

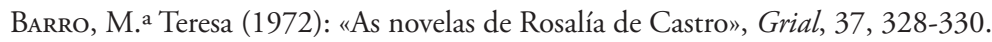

Ваум, Nina (1999): «Again and Again, the Scribbling Women», en John L. Idol, Jr. / Melinda M. Ponder (eds.), Hawthorne and Women. Engendering and Expanding the Hawthorne Tradition, Boston, University of Massachusetts, 20-35.

Broady, Donald (2002): «French Prosopography: Definition and Suggested Readings», Poetics, 30:5-6, 381-385.

Carballo Calero, Ricardo (1979): Estudos rosalianos. Aspectos da vida e da obra de Rosalía de Castro, Vigo, Galaxia.

Castro, Rosalía de (2005): La hija del mar. [Ed. Montserrat Ribao Pereira]. Madrid, Akal.

Cejador y Frauca, Julio (1918): Primer periodo de la época realista: 1850-1869, vol. 8 de Historia de la lengua y literatura castellana, Madrid, Tip. de la «Revista de Archivos, Bibl. y Museos».

CLÚA Ginés, Isabel (2012): «De abismos y superficies: nuevos espacios de lo gótico en El caballero de las botas azules», en Helena González Fernández / María do Cebreiro Rábade Villar (eds.), Canon y subversión. La obra narrativa de Rosalía de Castro, Barcelona, Icaria, 159-177.

Costa Clavell, Xavier (1985): Rosalía de Castro, Sada (A Coruña), Ediciós do Castro.

Establier Pérez, Helena (2010): «La traducción de las escritoras inglesas y la novela española del primer tercio del siglo xix: lo histórico, lo sentimental y lo gótico", Revista de Literatura, 72, 95-118.

García JáÑEz, Francisca (2005): «Faustina Sáez de Melgar, escritora y “ángel del hogar”, imagen plásticoliteraria», en Luis F. Díaz Larios et al. (eds.), Lectora, heroína, autora. La mujer en la literatura española del siglo XIX. III Coloquio de la Sociedad de Literatura Española del Siglo XIX, Barcelona, PPU, 135-148.

GuIlLÉn, Claudio (2005): Entre lo uno y lo diverso. Introducción a la Literatura Comparada (Ayer y hoy), Barcelona, Tusquets.

Hogle, Jerrold E. (2004): «Introduction: The Gothic in Western Culture», en Jerrold E. Hogle (ed.), The Cambridge Companion to Gothic Fiction, Cambridge, Cambridge University Press, 1-20.

Hurley, Kelly (2004): «British Gothic Fiction, 1885-1930», en Jerrold E. Hogle (ed.), The Cambridge Companion to Gothic Fiction, Cambridge, Cambridge University Press, 189-207.

JAEGER, Hans (1977): «Generationen in der Geschichte: Überlegungen zu einer umstrittenen Konzeption», Geschichte und Gesellschaft, 3, 429-452.

LÉvY, Maurice (1995): Le Roman "gothique» anglais 1764-1824, París, Albin Michel.

López Santos, Miriam (2010): La novela gótica en España (1788-1833), Vigo, Academia del Hispanismo.

Lundén, Rolf, / Bo G. Ekelund / Mattias Bolkéus Blom (2002): «Literary Generations and Social Authority: A Study of US Prose-Fiction Debut Writers, 1940-2000», Poetics, 30:5-6, 299-309. 
Mayoral, Marina (1986): «La voz del narrador desde La hija del mar a El primer loco: un largo camino hacia la objetividad narrativa», en Actas do Congreso internacional de estudios sobre Rosalía de Castro e o seu tempo, Santiago de Compostela, Consello da Cultura Galega / Universidade de Santiago de Compostela, I, 341-366.

Mercer, Leigh (2012): «Shadowing the Gothic: Rosalía de Castro’s La hija del mar and Benito Pérez Galdós’s La sombra», Decimonónica, 9:1, 34-47.

Milbank, Alison (2004): «The Victorian Gothic in English Novels and Stories», en Jerrold E. Hogle (ed.), The Cambridge Companion to Gothic Fiction, Cambridge, Cambridge University Press, 145-165.

Moretti, Franco (2001): Atlas de la novela europea 1800-1900. [Trad. Mario Merlino]. Madrid, Trama.

Moretti, Franco (2005): Graphs, Maps, Trees. Abstract Models for a Literary History, Londres, Verso.

Murguía, Manuel (1857): «La flor. Poesías de la señorita Dońa Rosalía de Castro», La Iberia, 12 de maio.

Norton, Rictor (2000): Gothic Readings: The First Wave, 1764-1840, Londres, Continuum.

Ribao Pereira, Montserrat (2012): «A biblioteca de Rosalía de Castro», Grial, 194, $42-47$.

SAvoy, Eric (2004): «The Rise of American Gothic», en Jerrold E. Hogle (ed.), The Cambridge Companion to Gothic Fiction, Cambridge, Cambridge University Press, 167-188.

Urrutia, Jorge (1983): «El camino cerrado de Gaspar Núñez de Arce», Anales de Literatura Española, 2, 491-508. 
